\title{
EFFECT OF BENTONITE CONCENTRATION ON PROPERTIES AND REGULARITY OF CRYSTALLIZATION OF NANOCOMPOSITE MATERIALS BASIS ON THE OF MIXTURES OF HIGH AND LOW DENSITY POLYETHYLENE
}

\author{
F.A.Mustafayeva, N.T.Kakhramanov, N.B.Arzumanova, N.Ya.Ishenko, I.A.Ismayilov \\ Institute of Polymer Materials of Azerbaijan National Academy of Science \\ najaf1946@rambler.ru
}

Received 04.03.2019

Accepted 21.10.2019

\begin{abstract}
The results of research of the effect of bentonite concentration on the regularity of crystallization and the nature of changes of ultimate tensile strength, tensile yield strength and elongation at break of nanocomposite materials basis of on the mixtures of high and low density polyethylene presents.
\end{abstract}

Keywords: crystallization, dilatometry, specific volume, polymer blend, high-density polyethylene, lowdensity polyethylene, bentonite.

doi

\section{Introduction}

The thermophysical properties of polymers predetermine the operating conditions for the use of polymeric materials. Polyolefins have relatively low values of thermophysical properties, in particular, low melting point, heat resistance. In addition, in accordance with the increasing requirements, most polymers, including polyolefins, must have relatively high flammability resistance, that is usually achieved by adding flame-retardants to their composition directly during the melt blending process [1]. In this regard, has significantly increased interest in the use of environmentally friendly flame-retardant systems, to the number of which are polymer nanocomposites on the basis layered silicates [2-4].

Polymer-mineral nanocomposites are a relatively materials based on the reinforcement of their by dispersing nanosized filler particles at the molecular level. From this point of view, polymer-clay nanocomposites demonstrate an exceptional improvement in mechanical properties, including rigidity, strength, dimensional stability, a significant increase in thermal stability, as well as self-damping and fire resistance characteristics [5].

Montmorillonite improves the rheological, mechanical, thermal properties of both thermoplastic and elastomeric polymer matrices. They found important commercial applications in various fields of technology. In this regard, in this work, an attempt has been made to substantiate scientifically these improvements taking into account the effect of the ratio of mixture components on the regularity of changes in the basic physico-mechanical properties of nanocomposites on the basis of a mixture of polymers and bentonite. Considering that the physicomechanical properties of polymer composites depend on their structure and processes occurring at the interface, the purpose of this work was to investigate the regularity of changes in the structure and properties of nanocomposites depending on the concentration of bentonite.

\section{Experimental part}

The object of research was composite materials obtained on the basis of a mixture of industrial samples of high density polyethylene (HDPE) and low density polyethylene (LDPE) in the ratio of 50/50 and natural mineral filler bentonite.

HDPE: ultimate tensile strength - 28.4 $\mathrm{MPa}$, tensile yield strength - 35.3 MPa, elongation at break $-350 \%$, density $-963 \mathrm{~kg} / \mathrm{m}^{3}$, melt flow rate (MFR) - $1.7 \mathrm{~g} / 10 \mathrm{~min}$, melt point $135^{\circ} \mathrm{C}$, heat resistance $-128^{\circ} \mathrm{C}$, degree of crystallinity $-78 \%$.

LDPE: ultimate tensile strength -8.7 $\mathrm{MPa}$, tensile yield strength $-11.1 \mathrm{MPa}$, elongation at break $-580 \%$, density $-912 \mathrm{~kg} / \mathrm{m}^{3}$, MFR $-7.8 \mathrm{~g} / 10 \mathrm{~min}$, melt point $-103^{\circ} \mathrm{C}$, heat resistance $-85^{\circ} \mathrm{C}$, degree of crystallinity $-60 \%$.

Bentonite clays consist of $60-70 \%$ or more percent of the minerals of the smectite group (montmorillonite, nontronite, beidelite 
etc.). The general formula of bentonite clays is $\mathrm{Al}_{2} \mathrm{O}_{3} \cdot 4 \mathrm{SiO}_{2} \cdot n \mathrm{H}_{2} \mathrm{O}$. Montmorillonite is most often a rock-forming component in bentonite clays. The crystal lattice of montmorillonite is consists from two structural elements. One of these elements includes two outer silicon-oxygen tetrahedrons, in the center of each is a silicon atom that is equidistant from four oxygen atoms or hydroxyl groups. The rows of silicon-oxygen tetrahedrons are arranged in the form of infinitely repeating hexagonal grids. The second structural element of the crystal lattice of montmorillonite consists of close-packed oxygen atoms or hydroxyl groups, aluminum atoms are located between them in an octahedral combination. The alumo-oxygen octahedral mesh in the structure of montmorillonite is located between two silicon-oxygen tetrahedra. The articulation of these two tetrahedral and one octahedral meshes is forms common layers [6].

Nanocomposite materials basis of on the a mixture of HDPE and LDPE (50/50) and with different concentrations of bentonite $(1,3,5$, 10, 20 and 30 mass \%) were obtained on laboratory rollers at a temperature of $150^{\circ} \mathrm{C}$ within 8 10 minutes. Then, at a pressing temperature of $170^{\circ} \mathrm{C}$, plates were molded from which the corresponding samples were cut down for testing.

Dilatometric studies were performed on an IIRT-1 device with a load of $5.3 \mathrm{~kg}$ and in the temperature range from $180^{\circ} \mathrm{C}$ to room temperature.

The melting point was determined on a Q-1500 D derivatograph of the firm MOM (Hungary) of the Paulik-Paulik-Erdei system.

The density of the compositions at a temperature of $190^{\circ} \mathrm{C}$ was determined on a capillary rheometer of the brand MELT FLOW TESTER, CEAST MF50 (INSTRON, Italy).

Heat resistance was determined by the method of Vika (apparatus of the company VEB Thüringer Industriewerk Rauenstein) in accordance with GOST 15088-83.

Ultimate tensile strength $\left(\sigma_{\mathrm{ts}}, \mathrm{MPa}\right)$, tensile yield strength $\left(\sigma_{\mathrm{ys}}, \mathrm{MPa}\right)$ and elongation at break $(\varepsilon, \%)$ of the obtained compositions and the initial polymer were determined in accordance with GOST 11262-80.

The particle size of bentonite was determined on a laser analyzer brand Mastersizer 3000
(Malvern Instruments, England). The measuring range of the device is from $10 \mathrm{~nm}$ to $3500 \mathrm{mkm}$.

\section{Results and discussion}

Polyolefins are one of the most widely used polymeric materials, but the manufacture of alumina composites basis of on the polyolefins is still a serious problem for researchers. This is mainly due to the non-polar nature of the polyolefins and the high hydrophilicity of the clay [5]. To obtain a complete picture of the crystallization process, and the effect of bentonite concentration on the crystallization temperature and density of nanocomposite materials based on bentonite+HDPE/LDPE, it was initially interesting to consider their thermophysical and physico-mechanical characteristics at various bentonite concentrations. It should be noted that, for the all researched samples of composite materials, a mixture of HDPE and LDPE was taken at a 50/50 ratio.

Table 1 summarizes the results of a research of the effect of bentonite concentration on ultimate tensile strength, tensile yield strength, elongation at break and heat resistance of the bentonite +HDPE/LDPE system.

Analyzing the data given in Table 1, you can see that with the loading of the 1 mass $\%$ of bentonite into composition of the polymer mixture some increase in $\sigma_{\text {ys }}$ of samples up to 21.6 $\mathrm{MPa}$ and $\sigma_{\mathrm{ts}}$ up to $15.5 \mathrm{MPa}$ is observed.

Table 1. The effect of the concentration of bentonite on the physico-mechanical properties of nanocomposites on the basis of a mixture of high and low density polyethylene

\begin{tabular}{|c|c|c|c|c|}
\hline $\begin{array}{c}\text { *The composition } \\
\text { of the composite, } \\
\text { mass } \%\end{array}$ & 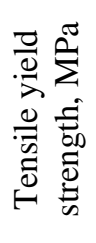 & 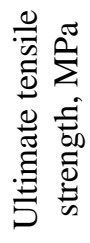 & 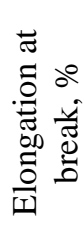 & 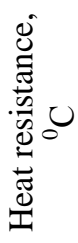 \\
\hline HDPE/LDPE & 20.7 & 14.5 & 480 & 112 \\
\hline HDPE/LDPE+1 B & 21.6 & 15.5 & 450 & 112 \\
\hline HDPE/LDPE+3 B & 19.8 & 13.0 & 370 & 114 \\
\hline HDPE/LDPE+5 B & 19.3 & 12.8 & 65 & 114 \\
\hline HDPE/LDPE+10 B & 19.4 & 12.7 & 40 & 115 \\
\hline HDPE/LDPE+20 B & 19.2 & 16.3 & 30 & 117 \\
\hline HDPE/LDPE+30 B & 18.2 & 15.7 & 30 & 118 \\
\hline
\end{tabular}

* - a mixture of HDPE and LDPE were taken in a 50/50 ratio, $\mathrm{B}$ - bentonite. 
With a further increase in the amount of bentonite to $30 \mathrm{wt} . \%$ the $\sigma_{\mathrm{ys}}$ decreases from 21.6 $\mathrm{MPa}$ to $18.2 \mathrm{MPa}$ (that is, by $3 \mathrm{MPa}$ ). Increases in the concentration of bentonite (over 1\%) in the composite, at first, a regular decrease in the ultimate tensile strength is observed, but at 30 mass $\% \sigma_{\mathrm{ts}}$ concentration reaches a higher value than the initial polymer matrix. The latter circumstance suggests that bentonite, as a filler, plays a reinforcing role. At 1 mass $\%$ of the bentonite amount in the mixture (bentonite+ HDPE/LDPE) shows a slight decrease in the elongation at break from 480 to $450 \%$. With further increase in the amount of bentonite, a natural decrease in the elongation at break of the composites is noticed. As mentioned earlier, this is due to the fact that the compatibility of polyethylene with clay fillers is relatively low.

As can be seen from Table 1, with an increase in the concentration of bentonite, an increase in the heat resistance of nanocomposites from 112 to $118^{\circ} \mathrm{C}$ observed. The increase in heat resistance of composites is due to the fact that the filler particles accumulating in amorphous regions is increase the density of the entire composition. In this case, in a certain way, there is a decrease in the mobility of the "feedthrough" chains, which directly affects the increase in heat resistance and softening point of polymeric materials.

This confirmed by the results of a research of the melting point of the nanocomposites. According to the data of a derivatographic analysis, the melting point of the composites changes in the following sequence: HDPE/LDPE $-120^{\circ} \mathrm{C}$, $\mathrm{HDPE} / \mathrm{LDPE}+1 \%-120^{\circ} \mathrm{C}, \mathrm{HDPE} / \mathrm{LDPE}+3 \%-$ $120^{\circ} \mathrm{C}, \quad \mathrm{HDPE} / \mathrm{LDPE}+5 \%-121^{\circ} \mathrm{C}, \mathrm{HDPE} /$ $\mathrm{LDPE}+10 \%-123^{0} \mathrm{C}, \quad \mathrm{HDPE} / \mathrm{LDPE}+20 \%-$ $125^{\circ} \mathrm{C}, \mathrm{HDPE} / \mathrm{LDPE}+30 \%-125^{\circ} \mathrm{C}$. As can be seen from the above data, when the concentration of bentonite is more than 10 mass\% there is a slight increase in the melting point of composite materials, i.e. more thermal energy is required for the thermofluctuationar destruction of the supramolecular structure of the composites.

To obtain sufficiently complete information on the physico-chemical processes occurring in the structure of the composites de- pending on the temperature factor, let us turn to the results of the study of changes in their phase and state of aggregation according to dilatometric measurements. Dilatometry shows the nature of the change in the dependence of the specific volume on temperature and determines the temperature of the first-order phase transition at the crystallization temperature.

Polymer crystallization studies are usually carried out using dilatometry, differential scanning calorimetry and optical microscopy. These methods are widely used in the analysis of crystallization kinetics using the Avrami equation [7]. In this study, it is possible to determine such properties as the temperature of the onset of crystallization, the glass transition temperature, density, specific volume, free or unoccupied volume, depending on the concentration of bentonite.

The study of the structure of low-density and high-density polyethylene blends using an optical method, depending on their behavior during crystallization, showed [8] that the formation of spherulites and the increase in their size before a collision occurs during the crystallization of high-density polyethylene, forming the initial moment of the spherulites skeleton.

Table 2 shows the results of studying the effect of the concentration of bentonite on the temperature of the onset of crystallization of the density of the considered nanocomposite materials at room temperature and at $190^{\circ} \mathrm{C}$.

Table 2. The effect of bentonite concentration on the density and temperature of the onset of the process of crystallization of nanocomposites based on a mixture of high and low density polyethylene

\begin{tabular}{|c|c|c|c|}
\hline $\begin{array}{c}\text { *The composition } \\
\text { of the composite, } \\
\text { mass } \%\end{array}$ & 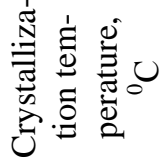 & 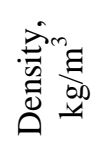 & 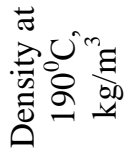 \\
\hline HDPE/LDPE & 115 & 0.940 & 0.730 \\
\hline HDPE/LDPE+1 B & 115 & 0.939 & 0.714 \\
\hline HDPE/LDPE+3 B & 110 & 0.955 & 0.742 \\
\hline HDPE/LDPE+5 B & 110 & 1.021 & 0.747 \\
\hline HDPE/LDPE+10 B & 112 & 1.086 & 0.808 \\
\hline HDPE/LDPE+20 B & 113 & 1.150 & 0.852 \\
\hline HDPE/LDPE+30 B & 113 & 1.262 & 0.749 \\
\hline
\end{tabular}

* - a mixture of HDPE and LDPE were taken in a 50/50 ratio, B-bentonite 
As can be seen, 1 mass $\%$ content of bentonite in a mixture of LDPE/HDPE does not have any change on the temperature of the beginning of the crystallization process, and is equal to $115^{\circ} \mathrm{C}$. Density at room temperature is also remains unchanged, but for density at a temperature of $190^{\circ} \mathrm{C}$ there is a slight decrease. For composite materials with a concentration of bentonite in the range of 3-30 mass\% phase transition of the first order occurs at a temperature range of $110-113^{0} \mathrm{C}$. The density corresponding to room temperature for these materials is naturally increases. With increasing concentration of bentonite from 3 to 20 mass\% there is an increase in the density value, and a sharp decrease for the HDPE/LDPE blend +30 mass $\%$ bentonite (at $190^{\circ} \mathrm{C}$ temperature). The described properties are reflected in figure-1, representing the effect of the concentration of bentonite on the regularity of change in the specific volume from temperature.

The upper branches of the isotherm directly is reflect a decrease in the specific volumedistance between the packs of macromolecules and, accordingly, an increase in the melt density of the composites with an increase in the amount of bentonite in the composition. As is known, polymer nanocomposites based on layered silicates contain polymer molecules embedded in

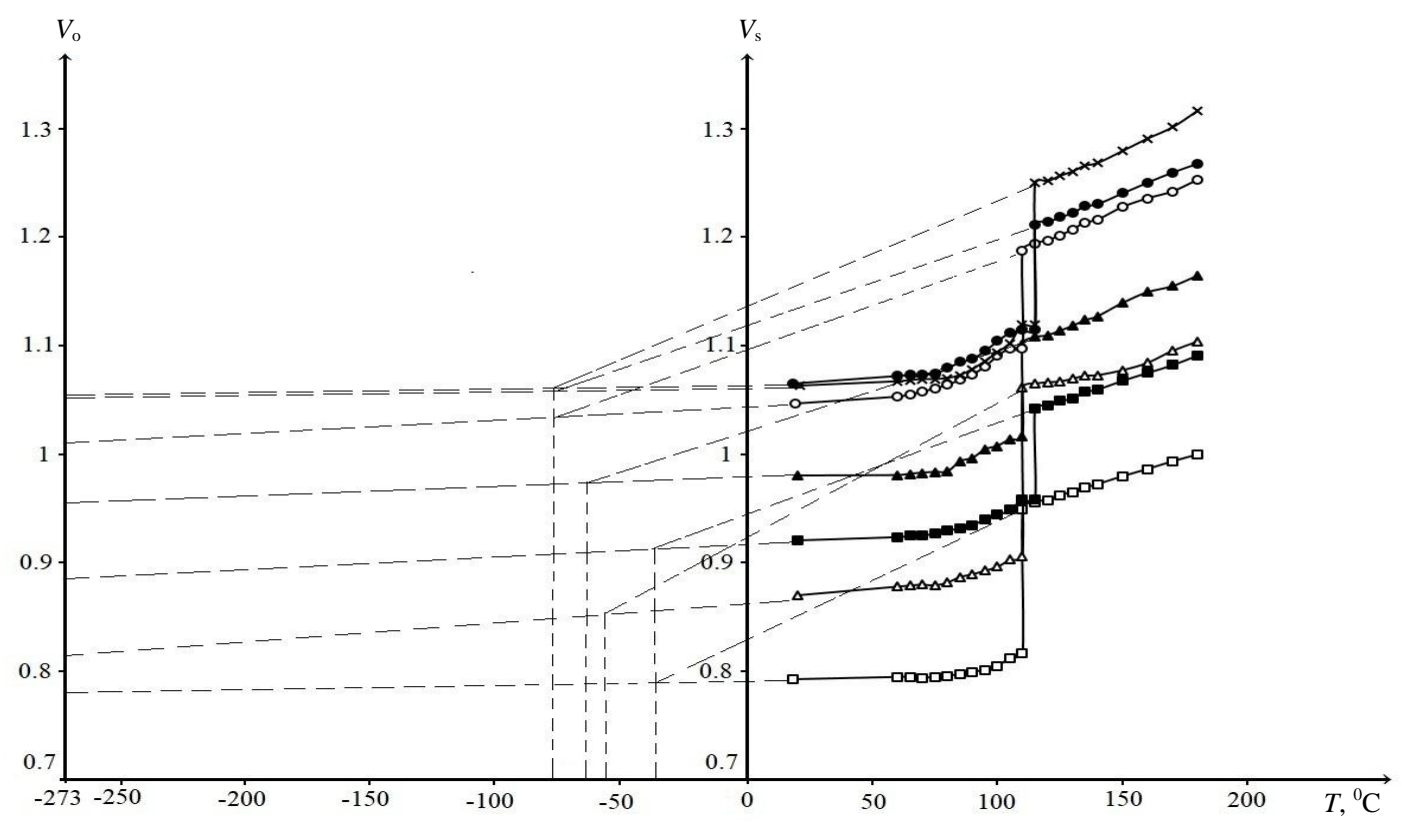

Fig. 1. Effect of bentonite concentration on the regularity of the change of the specific volume from temperature for nanocomposites, mass $\%: \times-\mathrm{HDPE} / \mathrm{LDPE}, \bullet-\mathrm{HDPE} / \mathrm{LDPE}+1 \%$ bentonite, $\circ-\mathrm{HDPE} / \mathrm{LDPE}+3 \%$ bentonite, $\boldsymbol{\Delta}-$ $\mathrm{HDPE} / \mathrm{LDPE}+5 \%$ bentonite, $\Delta-\mathrm{HDPE} / \mathrm{LDPE}+10 \%$ bentonite, $-\mathrm{HDPE} / \mathrm{LDPE}+20 \%$ bentonite, $\square-\mathrm{HDPE} / \mathrm{LDPE}+$ $30 \%$ bentonite. the interlayer space. In this research, bentonite with a nanoparticle size in the range of 80-120 $\mathrm{nm}$ was used. The sharp decrease in elongation with the addition of 5 mass $\%$ bentonite in a mixture of HDPE/LDPE can apparently be associated with bad compatibility of the matrix and filler particles, indicating to the formation of a nonintercalated nanocomposite. The growth of polyethylene spherulites is changing from the threedimensional to two-dimensional with the addition of plate silicate. In addition, the isothermal total crystallization rate is increases in the presence of clay due to the increased nucleation rate and decrease in the crystal growth rate [9]. The lower branches of the curves are reflect the processes occurring after crystallization, the samples are compressed and the density increases. As can be seen from the curves during the crystallization of composites, with an increase in the amount of filler, the specific volume is decreases, which is indicates an increase in the density of samples in the solid and molten state.

By the method of intersection of the upper and lower branches of dilatometric curves, the approximate values of the glass transition temperature of the studied nanocomposite materials were found (Figure 1). 
The glass transition temperature of the original HDPE/LDPE and its mixtures with the $1,3,5,10,20,30$ mass $\%$ filler is corresponds to $-73,-73,-73,-65,-58,-34,-34^{0} \mathrm{C}$. The free volume $\left(V_{\mathrm{f}}\right)$ of the samples under consideration was determined by the method of calculating the $V_{\mathrm{s}}-V_{\mathrm{o}}\left(V_{\mathrm{o}}-\right.$ occupied volume, $V_{\mathrm{s}}-$ specific volume), which is an integral property of the polymer matrix and is created by gaps left between the chains of polymeric bundles. Figure 2 shows the dependence of free volume on temperature for these composites.

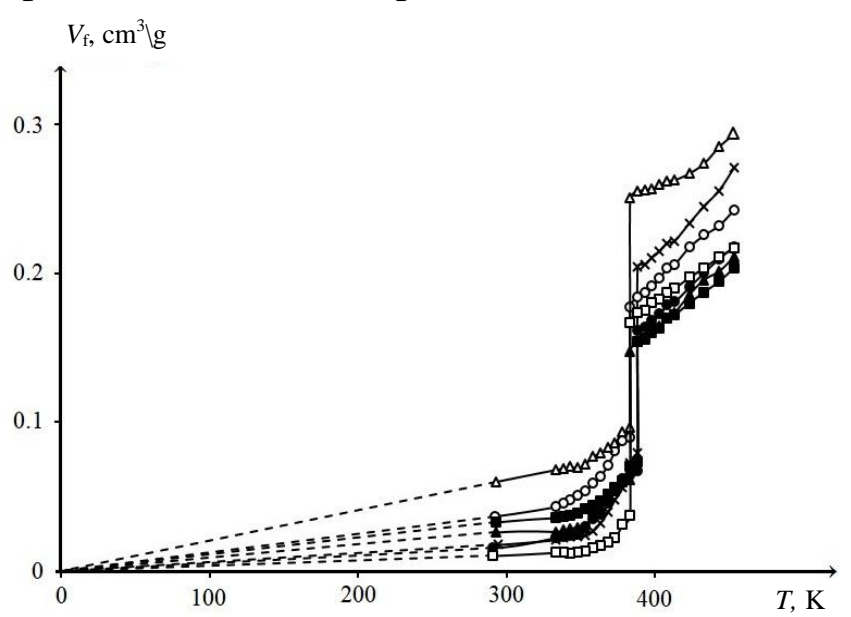

Fig. 2. Curves of changes in the free specific volume of the absolute temperature for nanocomposites, mass $\%$ : $\times-$ HDPE/LDPE, - - HDPE/LDPE $+1 \%$ bentonite, $\bigcirc-$ $\mathrm{HDPE} / \mathrm{LDPE}+3 \%$ bentonite, $\boldsymbol{\Delta}-\mathrm{HDPE} / \mathrm{LDPE}+5 \%$ bento-nite, $\Delta-\mathrm{HDPE} / \mathrm{LDPE}+10 \%$ bentonite, - HDPE/LDPE $+20 \%$ bentonite, $\square-$ HDPE/LDPE $+30 \%$ bentonite.

From a comparative analysis of the curves, it can be established that the loading of bentonite into the composition of the polymer mixture helps to reduce the free specific volume. This fact suggests that the filler particles are mainly embedded in the free volume of the polymers.

As a result of the conducted research it can be stated that in nanocomposite materials based on bentonite+HDPE/LDPE with an increase in the concentration of bentonite over 1 mass $\%$ there is a slight decrease in tensile yield strength, with a simultaneous increase in ultimate tensile strength and heat resistance, a gradual decrease in elongation, an increase in the density of composites identified at room temperature and at $190^{\circ} \mathrm{C}$, and a corresponding decrease in specific volume. The temperature of onset of crystallization for composites with the composition of HDPE/LDPE, HDPE/LDPE+1\% bentonite is $115^{\circ} \mathrm{C}$, and for the rest of the studied samples $110-113^{0} \mathrm{C}$. For the all examined samples were found the glass transition temperatures and the free volume was calculated.

\section{References}

1. Agwuncha S.C., Ibrahim I.D., Sadiku E.R. 14 Improving the thermal and flame resistance properties of polyolefins. Polyolefin fibres: Structure, properties and industrial applications. Edited by: Ugbolue S.C.I. Elsevier. 2017. P. 421-448.

2. Oliveira S.V., Araujo E.M., Pereira C.M.C., Leite. Polyethylene/bentonite clay nanocomposite with flame retardant properties. Polymeros-Ciencia e Tecnologia. Special issue. V. 27. 2017. P. 91-98.

3. Beyer G. Nanocomposies: a new class of flame retardants for polymers. Plastics, additives and compounding. V. 4. No 10. 2002. P. 22-28.

4. Ahmed L., Zhang B., Hatanaka L.C., Mannan. Application of polymer nanocomposites in the flame retardancy study. Journal of loss prevention in the process industries. V. 55. 2018. P. 381-391.

5. Kalgaonkar R.A., Jog J.P. 13 Polyolefin/clay nanocomposites. Nanofibers and nanotechnology in textiles. Edited by: Brown P.J., Stevens K. Woodhead. Publishing Limited. 2007. P. 351-385.

6. Mostal'gina L.V., Elizarova S.N., Kostin A.V. Bentonitovye gliny Zaural'ya: ekologiya i zdorov'e cheloveka. Kurgan: Izd-vo Kurganskogo gosudarstvennogo universiteta. 2010. $148 \mathrm{~s}$.

7. Teh J.W., Blom H.P., Rudin A. A study on the crystallization behaviour of polypropylene, polyethylene and their blends by dynamic mechanical and thermal methods. Polymer. V. 35. No 8. 1994. P. 1680-1687.

8. Fikhtner R.R., Volkov T.I., Shalatskaya S.A., Trizno M.S. Study of crystallization of industrial polyethylene and polyethylene mixture. Polymer Science U.S.S.R. V. 21. No 10. 1979. P. 25962603.

9. Peneva Y., Minkova L. Non-isothermal and isothermal crystallization of nanocomposites based on functionalized polyethylenes. Polymer Testing. V. 23. No 3. 2006. P. 366-376. 


\section{BENTONITIN QATILIĞININ AŞAĞI Və YUXARI SIXLIQLI POLIETTILEN QARIŞIĞI OSASINDA OLAN NANOKOMPOZIT MATERIALLARIN XÜSUSIYYYTLəRINə Və KRISTALLAŞMA QANUNAUYĞUNLUĞUNA TOSIRİ}

F.尹.Mustafayeva, N.T.Qəhrəmanov, N.B.Arzumanova, N.Y.İșenko, İ.A.İsmayılov

Məqalədə bentonitin qatılığının aşağı və yuxarı sıxlıqlı polietilen qarışığı əsasında olan nanokompozit materialların kristallaşma qanunauyğunluqlarına və dartılmada möhkəmlik həddi, dartılmada axıcılıq həddi, nisbi uzanma xüsusiyyətlərinin dəyişməsinə təsirini əks etdirən tədqiqatların nəticələri təqdim olunmuşdur.

Açar sözlor: kristallaşma, dilatometriya, xüsusi hacm, polimer qarılsı̆̆l, yuxarı sıxlıqlı polietilen, aşağı sıxlıqlı polietilen, bentonit.

\section{ВЛИЯНИЕ КОНЦЕНТРАЦИИ БЕНТОНИТА НА СВОЙСТВА И ЗАКОНОМЕРНОСТЬ КРИСТАЛЛИЗАЦИИ НАНОКОМПОЗИТНЫХ МАТЕРИАЛОВ НА ОСНОВЕ СМЕСЕЙ ПОЛИЭТИЛЕНА ВЫСОКОЙ И НИЗКОЙ ПЛОТНОСТИ}

\section{Ф.А.Мустафаева, Н.Т.Кахраманов, Н.Б.Арзуманова, Н.Я.Ищенко, И.А.Исмайылов}

Приведены результаты исследований влияния концентрации бентонита на закономерность кристаллизации и характер изменения разрушающего напряжения, предела текучести при растяжении, относительного удлинения нанокомпозитных материалов на основе смесей полиэтилена высокой и низкой плотности.

Ключевые слова: кристаллизация, дилатометрия, удельный объем, смесь полимеров, полиэтилен высокой плотности, полиэтилен низкой плотности, бентонит. 